\title{
Groundwater Mineralization Analysis of Osisioma Local Government Area of Aba, Abia State, Nigeria
}

\author{
Adindu R. $\mathbf{U}^{1, *}$, Igboekwe M.U², Lebe Nnanna ${ }^{1}$ \\ ${ }^{1}$ Dept. of Physics/Electronics, Abia State Polytechnic, Aba. P.M.B 7166, Aba Nigeria \\ ${ }^{2}$ Department of Physics, Michael Okpara University of Agriculture, Umudike. P.M.B. 7267 Umuahia, Abia state, Nigeria
}

\begin{abstract}
Water is directly linked to human and animal health, so it has to be suitable for drinking. Its suitability depends on its characteristics. The objective of this study is to determine the quality and suitability of groundwater of Osisioma Local Government Area (L.G.A) of Aba, Abia State, Southeastern Nigeria, for drinking and domestic purposes or otherwise, through physiochemical analysis. Five (5) samples of borehole water were collected and analyzed. The physiochemical analysis showed that the water is tasteless, odorless and colourless. It was determined to be free from heavy metals contamination, like Lead, Arsenic, Mercury and Barium. Aluminum and Manganese were also not detected. A mean pH of 6.3 was recorded, while the highest calcium Hardness value recorded out of the five samples was $15 \mathrm{mg} / \mathrm{L}$. This indicates that the water is soft. Conductivity is low, $(23 \mu \mathrm{s} / \mathrm{cm}-145 \mu \mathrm{s} / \mathrm{cm})$. The chloride concentration is also low $(11 \mathrm{mg} / \mathrm{L}-22 \mathrm{mg} / \mathrm{L})$ while an average value of $0.15 \mathrm{mg} / \mathrm{l}$ of magnesium was detected. Copper falls within the range of $0.1 \mathrm{mg} / 1$ to $0.14 \mathrm{mg} / \mathrm{l}$, Phosphate ranged from $0.04 \mathrm{mg} / 1-0.7 \mathrm{mg} / 1$ and Zinc from $0.29 \mathrm{mg} / 1-0.34 \mathrm{mg} / 1$. All of these values are within the permissible limits of WHO drinking water standards.. Total Dissolved Solid was found to be, between $10 \mathrm{mg} / \mathrm{L}$ and $67 \mathrm{mg} / \mathrm{L}$. The groundwater was found to be safe, therefore the people of this area do not stand the health risk associated with heavy metals contaminated drinking water.
\end{abstract}

Keywords Physiochemical, Analysis, Groundwater Quality, Drinking Water Standard, Osisioma

\section{Introduction}

Groundwater constitutes over $90 \%$ of the world's readily available freshwater resources with remaining $10 \%$ in lakes, reservoirs, rivers and wetlands.[1] Water quality is extremely important because constant access to good quality water is necessary for life as well as the economy.[2] The presence of adequate supply of quality water for human consumption is essential for sustainable development program of any society. The chemical composition of ground water is a measure of its suitability as a source of water for human consumption or for other usages like Agricultural and Industrial purposes.

Groundwater hydro-geochemistry Is mainly affected by the geological formations that the water passes through during its course and by anthropogenic activities.[3-6]). In some cases natural water may contain elevated concentrations of several potentially toxic elements or microbiological contaminants that may lead to adverse effects on human health.[7,8.] Groundwater can be rich in dissolved solids, especially carbonates and sulfates of calcium and magnesium as well as chloride and bicarbonates, depending on the strata through which groundwater flow. In that case,

* Corresponding author:

ifynmic@yahoo.co.uk (Adindu R. U)

Published online at http://journal.sapub.org/chemistry

Copyright (C) 2012 Scientific \& Academic Publishing. All Rights Reserved additional treatment may be required in order to provide pleasant water for drinking and household use.

There are a lot of waste generation in Osisioma Local Government Area of Aba due to population increase, much commercial and artisans activities. These wastes are disposed of at open dumping landfills located at different parts of the city. Landfill leachate which is contaminated waste water produced in the process of decomposition when rain water percolates through the layers in landfill, has become an important and serious environmental problem in many societies.[9,10]. Yet, a lot of small scale water industries are striving well and having a fair share of the local economy. It is therefore the objective of this study to determine the quality and suitability of the groundwater for drinking and domestic purposes or otherwise, through physiochemical analysis of the water samples from this area and comparison of the results with WHO standards for drinking water.

\subsection{Location}

Osisioma Local Government Area Is located within Latitude $7^{\circ} 10^{\prime} \mathrm{E}$ and longitude $5^{\circ} 27^{\prime} \mathrm{N}$. It forms one of the major districts in Aba, the central commercial city of Abia State, South eastern Nigeria. It is highly populated, with an average population density of 3000 inhabitants per square kilometer. The people are predominately traders. See figures 1 and 2 (map of the study area). 


\subsection{Geology/Hydrogeology of the Area}

This area is underlain by the Benin Formation, consisting of coarse sands interrupted by clay lenses of Quaternary age. It has good aquiferous potential. The aquifer is about $1500 \mathrm{~m}$ thick. Depths to water are shallow $(8 \mathrm{~m}-26 \mathrm{~m})$. The area, has an average temperature of $27^{\circ} \mathrm{C}$, monthly maxima and minima deviating by no more than $5.5^{\circ} \mathrm{C}-6.5^{\circ} \mathrm{C}$.[11] It has two main seasons in a year. The rainy season occurring between March and October while the Dry Season prevails for the rest of the years. Its vegetation is characterized by tropical rainforest. Aba is generally drained by the Aba River and its tributaries.

\section{Materials / Method}

A litre of each of the water samples were collected from five (5) existing boreholes at Okpulumubo, World Bank, Umueze (Teaching Hospital), Faulks Road and Nweke. Each sample point is about $2.5 \mathrm{~km}$ away from each other. These

were collected in clean plastic bottles and taken to the laboratory within a space of an hour for treatment and analysis. The various analytical techniques implored are shown in Table 1.

Table 1. Analytical techniques implored

\begin{tabular}{|c|c|}
\hline Analysis & Techniques used \\
\hline $\mathrm{pH}$ & $\mathrm{pH}$ meter \\
\hline Calcium hardness & EDTA Titrametric method \\
\hline TDS, Salinity, Conductivity & Conductivity meter \\
\hline Heavy metals & Spectrophotometer \\
\hline Total acidity & Gravimetric method \\
\hline Colour & Lovibond comparator \\
\hline Temperature & Thermometer \\
\hline Turbidity & Turbido meter \\
\hline
\end{tabular}

\section{Results}

Table 2. The physiochemical analysis of the samples

\begin{tabular}{|c|c|c|c|c|c|c|c|c|}
\hline \multicolumn{9}{|c|}{ Physiochemical Analysis Result From Study Area Compared with WHO and NIS Standards } \\
\hline \multirow[b]{2}{*}{$\mathrm{S} / \mathrm{N}$} & \multirow[b]{2}{*}{ Test Parameters } & SP1 & SP2 & SP3 & SP4 & SP5 & \multirow{2}{*}{$\begin{array}{l}\text { WHO Stan- } \\
\text { dard Value }\end{array}$} & \multirow{2}{*}{$\begin{array}{c}\text { NIS } \\
\text { Value }\end{array}$} \\
\hline & & Okpulumubo & $\begin{array}{l}\text { World } \\
\text { Bank }\end{array}$ & $\begin{array}{l}\text { Teaching } \\
\text { Hospital }\end{array}$ & $\begin{array}{c}\text { Faulks } \\
\text { Road }\end{array}$ & Eziama & & \\
\hline 1 & Temperature $\left({ }^{\circ} \mathrm{C}\right)$ & 25 & 25 & 25 & 26 & 26 & - & Ambient \\
\hline 2 & Colour (TCU) & 3.0 & 3.0 & 3.0 & 3.0 & 3.0 & 15 & 3 \\
\hline 3 & Turbidity (NTU) & 5.0 & 5.0 & 5.0 & 5.0 & 5.0 & 5.0 & 5 \\
\hline 4 & $\mathrm{pH}$ & 6.3 & 6.6 & 6.3 & 6.1 & 6.0 & $6.5-8.5$ & $6.5-5.5$ \\
\hline 5 & Total hardness (mg/l) & 6.00 & 15.00 & 5.00 & 12.00 & 15.00 & 500 & 100 \\
\hline 6 & Total dissolved solids (TDS) (mg/l) & 25.00 & 29.00 & 10.00 & 67.00 & 63.00 & 1000 & 500 \\
\hline 7 & Conductivity (us/cm) & 56.00 & 63 & 23.00 & 145.00 & 137.00 & 1000 & 1000 \\
\hline 8 & Total acidity (mg/l) & 35.00 & 36.00 & 32.5 & 27.00 & 26.4 & 1.0 & - \\
\hline 9 & Iron $(\mathrm{mg} / \mathrm{l})$ & 0.05 & 0.04 & 0.04 & 0.09 & 0.08 & 0.30 & 0.3 \\
\hline 10 & Calcium (mg/l) & 2.13 & 3.19 & 1.72 & 3.06 & 3.72 & 200 & 75 \\
\hline 11 & Magnesium (mg/l) & 0.15 & 0.15 & 0.14 & 0.16 & 0.16 & 0.02 & 0.02 \\
\hline 12 & Lead mg/l) & ND & ND & ND & ND & ND & 0.01 & 0.01 \\
\hline 13 & Arsenic (mg/l) & ND & ND & ND & ND & ND & 0.01 & 0.01 \\
\hline 14 & Copper (mg/l) & 0.10 & 0.11 & 0.04 & 0.14 & 0.12 & 2.0 & 1.0 \\
\hline 15 & Zinc (mg/l) & 0.31 & 0.32 & 0.29 & 0.34 & 0.31 & 3.0 & 5.0 \\
\hline 16 & Mercury (mg/l) & ND & ND & ND & ND & ND & 0.001 & 0.001 \\
\hline 17 & Alkalinity $(\mathrm{mg} / \mathrm{l})$ & 60.0 & 65.00 & 50.00 & 45.00 & 40.00 & 200 & 200 \\
\hline 18 & Chloride (mg/l) & 12.00 & 14.00 & 11.00 & 22.00 & 18.00 & 250 & 100 \\
\hline 19 & Nitrate $(\mathrm{mg} / \mathrm{l})$ & 8.59 & 9.79 & 8.26 & 12.37 & 10.49 & 50 & 10.0 \\
\hline 20 & Odour & OL & OL & $\mathrm{OL}$ & $\mathrm{OL}$ & OL & $\mathrm{OL}$ & $\mathrm{OL}$ \\
\hline 21 & Taste & $\mathrm{TL}$ & $\mathrm{TL}$ & $\mathrm{TL}$ & $\mathrm{TL}$ & $\mathrm{TL}$ & $\mathrm{TL}$ & $\mathrm{TL}$ \\
\hline 23 & Aluminum & ND & ND & ND & ND & ND & 0.2 & 0.2 \\
\hline 24 & Manganese & ND & ND & ND & ND & ND & 0.5 & 0.2 \\
\hline 25 & Barium (mg/l) & ND & ND & ND & ND & ND & 0.7 & 0.7 \\
\hline 26 & Phosphate (mg/l) & 0.70 & 0.04 & 0.4 & 0.47 & 0.52 & 0.54 & - \\
\hline 27 & Total suspended solid(mg/l) & 75.0 & 71.0 & 90.0 & 133.0 & 137.0 & - & - \\
\hline
\end{tabular}

NOTE: ND - Not detected, TCU - True Colour Unit, NTU - Nephelometric Turbidity Unit, SP- Sample, NIS - Nigerian Industrial Standard 
Table 3. Suitability of Groundwater for drinking based on TDS values / water class after Venu et al.,[12]

\begin{tabular}{|c|c|c|c|c|c|c|c|}
\hline TDS(mg/1) & Water class & \multicolumn{5}{|c|}{ Sample Result } & \multicolumn{2}{c|}{ Remark } \\
\hline & & SP1 & SP2 & SP3 & SP4 & SP5 & Excellent \\
\hline$<300$ & Excellent & 25 & 29 & 10 & 67 & 63 & - \\
\hline $300-600$ & Good & - & - & - & - & - & - \\
\hline $600-900$ & Fair & - & - & - & - & - & - \\
\hline $900-1200$ & Poor & - & - & - & - & - & - \\
\hline$>1,200$ & Unacceptable & - & - & - & - & - & \\
\hline
\end{tabular}

Table 4.

\begin{tabular}{|c|c|c|c|c|c|c|c|}
\hline \multicolumn{8}{|c|}{ Suitability of Groundwater for drinking Based on Total Hardness (CaCO3mg/l) after Sawyer and McCartly (1967)[13] } \\
\hline $\begin{array}{c}\text { Total Hardness } \\
\left(\mathrm{CaCO}_{3} \mathrm{mg} / \mathrm{l}\right)\end{array}$ & Classification & SP1 & SP2 & SP3 & SP4 & SP5 & Remark \\
\hline$<75$ & Soft & 6 & 15 & 5 & 12 & 15 & Soft \\
\hline $75-150$ & Moderately hard & - & - & - & - & - & - \\
\hline $150-300$ & Hard & - & - & - & - & - & - \\
\hline 300 & Very Hard & - & - & - & - & - & - \\
\hline
\end{tabular}

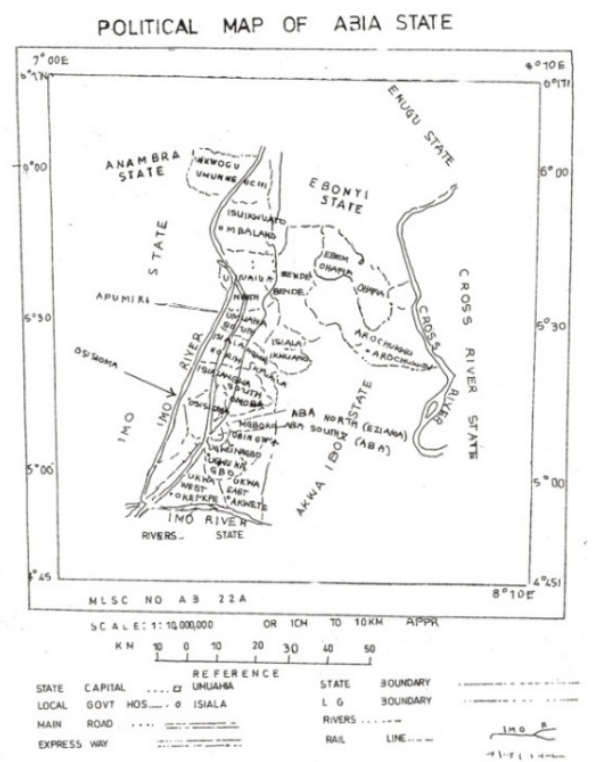

Figure 1. Political map of Abia State

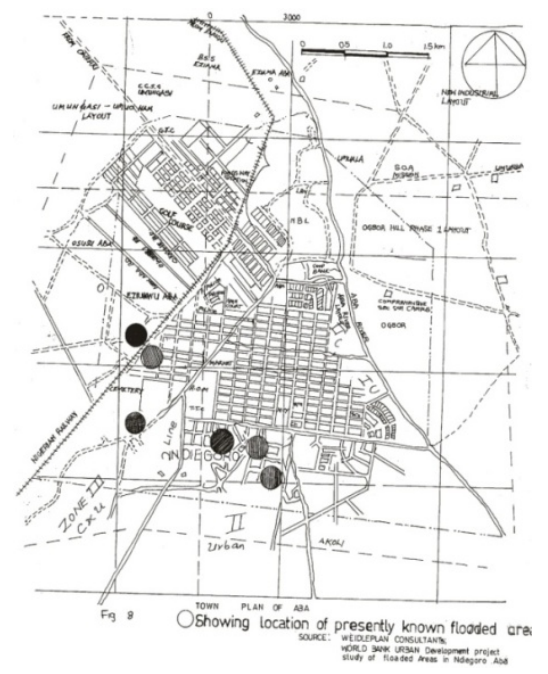

Figure 2. Town plan of Aba

\subsection{Colour, Appearance, Turbidity}

The colour indices for all the samples is 3.0 TCU, while turbidity is 5.0NTU. All the borehole water samples were colourless, tasteless and odourless,. This implies that there is an absence of decomposed vegetation, colloidal substances and suspended vegetation. These characteristics met the WHO standards for drinking water. Turbidity above 5.0NTU affects the appearance of the water.

\section{2. $\mathrm{pH}$}

$\mathrm{pH}$ is a measure of the hydrogen-ion concentration in a medium. The result showed that the $\mathrm{pH}$ of the water samples ranged from 6.0 - 6.3 as against the WHO standard value of $6.5-8.5$. This indicates acidity. The acidity may be attributed to the landfill gases arising from the dumpsites that have percolated through the porous sub-surfaces into the aquifer.

\subsection{Conductivity}

Electrical conductivity is a function of magnesium, calcium, sodium and sulphates. There is a significant variation in the conductivity of the water samples, ranging from a very low value of $23.00 \mu \mathrm{s} / \mathrm{cm}$ in SP3 to $135 \mu \mathrm{s} / \mathrm{cm}$ in SP5 and $145 \mu \mathrm{s} / \mathrm{cm}$ in SP4, therefore the salinity of the groundwater was classified into two categories: A fairly low salinity in SP (1 - 3), resulting to low mineral content and High Salinity values in samples $4 \& 5$. There is therefore a possible conclusion, that the water in later sample points are in contact with much inorganic constituents within the aquiferous materials as it tends to develop chemical equilibrium with its environment than the former.

\subsection{Total Dissolved Solids (TDS), Total Suspended Solids (TSS) and Total Hardness}

The dissolved solids are obtained by the difference between total solids and total Suspended solids.

$$
(T D S=T S-T S S)
$$

where $\mathrm{TS}=$ Total solids

When TDS values are between $20 \mathrm{mg} / 1$ and $1000 \mathrm{mg} / \mathrm{l}$, the water is classified as fresh. Between $1000 \mathrm{mg} / 1-10,000 \mathrm{mg} / 1$

\section{Discussion}


the water is considered brackish, while above is unacceptable.[14,15]. The physiochemical analysis of the samples shows a fairly good values of TDS $(2.5 \mathrm{mg} / 1-6.7 \mathrm{mg} / 1)$, that indicates low impurities.

The hardness $(\mathrm{CaCO} 3 \mathrm{mg} / \mathrm{l})$ was calculated as follows:

$$
\frac{(\text { Vol.of } 0.01 \mathrm{~m} \text { EDTA used } \times 1000)}{\text { vol.of sample taken }}
$$

Total Hardness ranged from $6 \mathrm{mg} / \mathrm{l}-15 \mathrm{mg} / \mathrm{l}$. This indicates that the water is soft and good for drinking and domestic purposes. The presence of calcium in all the samples with a range value of $2.13 \mathrm{mg} / 1$ to $3.72 \mathrm{mg} / 1$ confirms the fact that the groundwater is soft. The Benin formation is the source of calcium and iron in this area. It is characterized by silicates and feldspars.

\subsection{Heavy Metals: Lead, Arsenic, Barium and Mercury}

The presence of heavy metals in drinking water poses a serious threat to health. Drinking water containing Barium causes diarrhea, vomiting and abdominal cramps. Arsenic above $0.1 \mathrm{mg} / \mathrm{l}$ causes cancer. Lead also above the value of $0.01 \mathrm{mg} / 1$ in water causes cancer, affects the metabolism of vitamin $\mathrm{D}$, hypertension and metal development in infants. It's also toxic to central and peripheral nervous system. $[16,17]$. However these metals were not detected in all the samples.

\subsection{Aluminum, Manganese}

Manganese above $0.1 \mathrm{mg} / 1$ stains laundry and sanitary wares, while above $0.2 \mathrm{mg} / \mathrm{l}$ in drinking water causes Neurological disorder.[18] similarly, Aluminum above $0.2 \mathrm{mg} / 1$ may cause discoloration. The result showed that these metals were not detected.

\subsection{Magnesium}

An average value of $0.15 \mathrm{mg} / 1$ of magnesium was detected. This falls within the permissible limits of the WHO standard for drinking water. Above the value of $0.2 \mathrm{mg} / \mathrm{l}$, it affects the appearance, taste and odour of the water. There is therefore no possibility of the people residing in the study area to be associated with the health hazards that are linked with Heavy metals contaminated drinking water.

\subsection{Chloride}

Chloride is one of the major anions in water. It is generally associated with sodium. High concentration of chloride ions may result in an objectionably salty taste. Chloride contains greater than $40 \mathrm{mg} / \mathrm{l}$ in the coastal aquifer indicates salt water contamination.[19]. The chloride concentration in the samples ranged from $11 \mathrm{mg} / 1-22 \mathrm{mg} / \mathrm{l}$. This implies that there is no salt water intrusion into the aquifer and also an absence of source rock that host salt.

\subsection{Copper, Zinc, Phosphate, Nitrate}

Consumption of water contaminated by nitrates could lead to several adverse health effects.[20-22]. From the result of the analysis, the nitrate values were not acute $(8.26 \mathrm{mg} / 1-$
$12.37 \mathrm{mg} / \mathrm{l})$. Phosphate value ranged from $0.4 \mathrm{mg} / 1$ to $0.7 \mathrm{mg} / 1$. Copper falls within the range of $0.1 \mathrm{mg} / 1$ to $0.14 \mathrm{mg} / \mathrm{l}$, Phosphate ranged from $0.04 \mathrm{mg} / 1-0.7 \mathrm{mg} / \mathrm{l}$ and Zinc from $0.29 \mathrm{mg} / 1-0.34 \mathrm{mg} / 1$. All of these values are within the permissible limits of WHO drinking water standards. Copper value above $1 \mathrm{mg} / 1$ may cause gastrointestinal disorder.

\section{Conclusions}

This research work is aimed at investigating the suitability of the groundwater supply in Osisioma L.G.A of Aba, Southeastern Nigeria. The physiochemical analysis revealed that the present status of the groundwater in this area is safe and suitable for drinking and domestic purposes. There is an absence of Barium, Lead, Arsenic, Mercury, Aluminum and Manganese. The water is soft, odourless, tasteless and colourless. All other anions and cations recorded fall within the limits of WHO standards for drinking water. However, there is a sharp variation in electrical conductivity indicated by two sampled boreholes in this area i.e. SP4 and SP5. This means that the water in these sample points are in contact with much inorganic constituents within the aquiferous materials. The chloride concentration in the samples ranged from $11 \mathrm{mg} / 1-22 \mathrm{mg} / \mathrm{l}$, implying that there is no salt water intrusion into the aquifer. From the result obtained, Leachate contamination from the open landfill dumpsites, has not really affected the ground water of this area. However, a better and modern waste management technique is recommended in order to preserve and sustain the groundwater quality of Osisioma.

\section{REFERENCES}

[1] Asonye C. C, Okolie N.P, Okenwa E.E and Iwuanyanwu U.G (2007). "Some Physiochemical Characteristics and Heavymetal Profiles of Nigerian Rivers, streams and wetlands". African Journal of Biotechnology, vol. 6, No5, pp. 617-624.

[2] Absalon D., \& Matysik, M(2007). "Changes in Water Quality and Runoff in the upper Oder River Basin”. Geomorphology. Vol. 92(3-4),pp 106-118.

[3] Kelepertsis A., Alexakis, D., \& Skordas, K. (2006). “Arsenic, Antimony and other toxic elements in drinking water of Eastern Thessaly in Greece and its possible effects on human health". Environment Geology. Vol. 50, pp 76-84.

[4] Siegel R.F (2002). Environmental Geochemistry of potentially toxic mental. P 218. New York: Springer - Verlag Berlin Heidelberg.

[5] Stamatis G., Voudouris K. \& Karefilakis, F. (2001). "Groundwater pollution by heavy metal in historical mining area of Lavrio, Attaica, Greece". Water, Air and soil Pollution, 128, pp 61-83.

[6] Sullivan P.P., Agardy, J.F., Clark J.J.J (2005). The Environmental Science of Drinking Water. Elsevier Butterworth Heinemann. P 384. 
[7] WHO(2004). Background Document for Development of WHO Guidelines for Drinking water Quality, $3^{\text {rd }}$ Edition, WHO, Geneva.

[8] United State Environmental Protection Agency (2001). National Primary and Secondary Water Standard Rules \& Regulation. Federal Register, vol.66, no. 14.

[9] Kurniawan T.A, Lo W.H and Chan G.Y.S. (2006). "Radicals-Catalyzed Oxidation Reaction for Degradation of Recalcitrant compounds from landfill Leachate". Chemical Engineering Journal, vol. 125, No.1, pp. 35- 57.

[10] Atmaca E. (2009).“Treatment of Landfill Leachate by using Electro-Fenton Method". Journal of Hazardous Materials, vol. 163, No. 1, pp. $109-114$.

[11] Ebilla - Salmon and Partners Consulting Engineers (1993). "Abia state Rural water supply project Studies". Pp. 59- 63.

[12] Venu and Madhuri S. Rishi (2011). "Suitability Evaluation of Groundwater for Drinking purpose: A case study of Barnala, Punjab, India. The IUP Journal of Environmental sciences. Vol. V, No 2. Pp. 47- 58.

[13] Sawyer G.N and McCarthy D.L. (1967), Chemistry of Sanitary Engineers, $2^{\text {nd }}$ Edition, p. 5518, McGraw - Hill, New York.

[14] Davis S.N. \& De Wiest R.J.M. (1996). Hydrogeology. New York. John Wiley \& Sons. P. 453.
[15] Sawyer C.N., McCarthy D.L. \& Parkin G.F.(2003.) Chemistry of Sanitary Engineers, $5^{\text {th }}$ Edition, p. 752, McGraw - Hill, New York.

[16] WHO (1998) Guidelines for Drinking water Quality. $2^{\text {nd }}$ Edition.vol.2. Health criteria and other supporting Information. Pp. 940 -9491 Geneva.

[17] WHO (2007). International Drinking water standards, $3^{\text {rd }}$ Edition, WHO, Geneva.

[18] Udom G. J, Esu E.O and Ekwere S.J (1998) “Quality Status of Groundwater in Calabar Municipality, South Eastern Nigeria", Global Journal of Pure and Applied Sciences. Vol.4, No.2. pp. 163-169.

[19] Avery A.A.(1999). "Infantile Methemoglobinemia. Re-examing the role of Drinking Water Nitrates". Environmental Health Perspectives. 107, 583 - 586.

[20] Cantor, K.P. (1997) “Drinking Water \& Cancer". Cancer causes \& Control. Vol. 8, pp. 292-308.

[21] Jensen O. (1982.) "Nitrate in drinking water \& Cancer in Northern Jutlan, Denmark, with special reference to stomach cancer". Ecotoxicology \& Environmental safety. Vol. 6, pp. 258-267. 